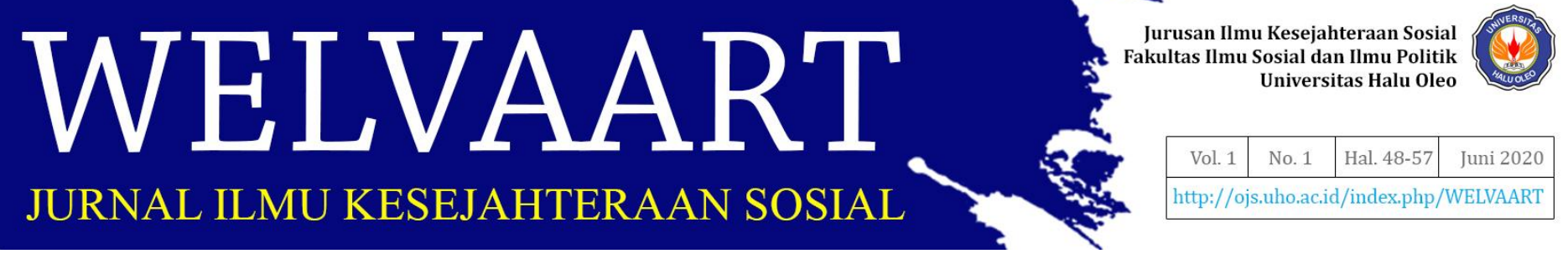

\title{
PENANGANAN ANAK BERMASALAH DENGAN HUKUM (ABH) DALAM KASUS TINDAK ASUSILA (Studi di Lembaga Pembinaan Khusus Anak Kelas II Kendari)
}

\author{
Sahrial G, Syaifudin S. Kasim, Sarpin \\ Universitas Halu Oleo
}

\begin{abstract}
ABSTRAK
Sahrial G (C1b3 14 055), Penanganan Anak Bermasalah Dengan Hukum (ABH) Dalam Kasus Tindak Asusila (Studi di Lembaga Pembinaan Khusus Anak Kelas II Kendari), dibawah bimbingan Drs.Syaifudin S. Kasim M, Si selaku pembimbing I dan Bapak Sarpin, S. Sos, M. Si selaku pembimbing II. Tujuan penelitian ini adalah untuk mengetahui bentuk kasus tindakan asusila yang dilakukan anak,kemudian faktor penyebab terjadinya kasus tindakan asusila yang dilakukan anak, dan bagaimana proses penanganan anak kasus tindak asusila di Lembaga Pembinaan Khusus Anak Kelas II Kendari. Metode penelitian yang digunakan dalam penelitian ini adalah deskriptif kualitatif, dimana teknik pengumpulan data menggunakan pengamatan, wawancara dan dokumentasi. Informan dalam penelitian ini anak binaan yang mendapatkan pembinaan, dan pegawai LPKA yang memberikan pembinaan kepada anak binaan dan pihak pekerja sosial sebagai informan tambahan. Hasil penelitian bahwa bentuk tindakan asusila yang dilakukan anak yaitu : (1). Ciuman dan Godaan yang di lakukan Pelaku terhadab Korban (2). Upaya Memaksa Salah Satu Pihak atau memaksa pihak yang satu agar menuruti kemauan pihak yang satu atas kemauan yang diinginkanya adapun Faktor - Faktor penyebab terjadinya tindakan asusila pada anak (1). Faktor Internal faktor yang terdapat dalam diri pelaku (2). Faktor Eksternal faktor yang berada diluar diri pelaku proses penanganan anak yang dilakukan di Lembaga Pembinaan Khusus Anak Kelas II Kendari (1). Proses Advokasi Anak proses bagaimana membantu anak dan keluarga mampu mendapatkan hak dan keadilan (2). Penerapan Pendidikan Agama (3). Penerapan Pendidikan Non Formal (Sekolah) Dalam LPKA atau usaha berfikir warga binaan semakin meningkat dan menunjang hal hal positif (4). Penerapan Pendekatan Informatif (informative approach) yaitu metode pemberian ilmu keterampilan untuk anak binaan LPKA (5). Pendekatan Partisipatif (partisivative approach) bagaimana anak dituntun memberikan pengetahuan terbaik mereka sesama anak binaan lainya (6). Pendekatan Experensial (experienscial approach) bagaimana menuntun anak terlibat langsung dalam proses penanganan atau di sebut belajar sejati.

Kata Kunci: Penanganan, Anak Berhadapan Dengan Hukum (ABH), Tindak Asusila
\end{abstract}

\section{PENDAHULUAN}

Negara Indonesia adalah negara yang menjunjung tinggi penegakan hukum dan hak asasi manusia. Hal ini karena hukum dan hak asasi manusia saling berkaitan satu sama lain. Hukum merupakan wadah yang mengatur segala hal mengenai perlindungan terhadap hak asasi manusia.

Anak adalah anugrah Tuhan Yang Maha Esa dan mereka perlu dilindungi harkat dan martabat selayaknya yang dimiliki oleh orang dewasa pada umumnya. Anak harus mendapatkan perlindungan khusus agar kelak dapat tumbuh dan berkembang dengan baik, anak sebagai penerus bangsa sebaiknya mendapatkan perlindungan bukan objek (sasaran) tindakan sewenang- 


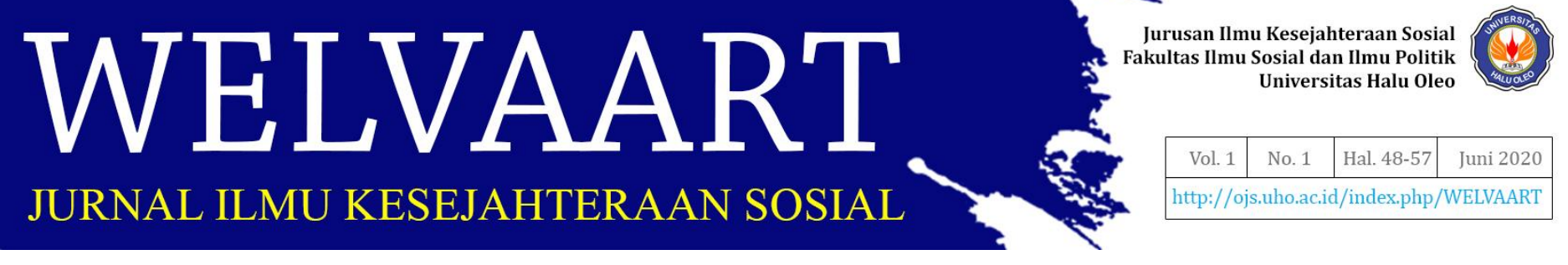

wenang dan perlakuan yang tidak manusiawi dari pihak manapun. Anak berhak mendapatkan perlindungan dan bantuan khusus keluarga sebagai inti dari masyarakat dan sebagai lingkungan alami bagi pertumbuhan dan kesejahteraannya.

Dalam kaitannya dengan persoalan perlindungan hukum bagi anak-anak, maka dalam UUD Negara RI Tahun 1945 pasa 134 telah ditegaskan bahwa "Fakir miskin dan anak terlantar di pelihara oleh negara". Secara umum perlindungan dan hak-hak anak juga dijamin oleh UUD Negara RI Tahun 1945 pada pasal 28 D ayat 2 yang berbunyi "Setiap anak berhak atas kelangsungan hidup, tumbuh, dan berkembang serta berhak atas prlindungan dari kekerasan dan diskriminasi".Ketentuan dalam UUD Negara RI Tahun 1945 memang tidak secara langsung memerintah terkait dengan anak-anak yang bermasalah dengan hukum, tetapi secara umum menegaskan perihal hak-hak dan perlindungan anak- anak. Ketentuan dalam UUD Negara RI Tahun 1945 kemudian ditegaskan dalam UU RI No 39 tahun 1999 tentang HAM, pasal 58 ayat 1 yang berbunyi "Setiap anak berhak untuk mendapatkan perlindungan hukum dari segala bentuk kekerasan fisik atau mental, penelantaran, perlakuan bentuk, dan pelecehan seksual selama dalam pengasuhan orang tua atau walinya, atau pihak lain manapun yang bertanggung jawab atas pengasuhan anak tersebut". Hal ini menunjukkan perhatian serius dari pemerintah terhadap hak-hak anak dan perlindungan anak.

Pengertian anak dalam hukum pidana lebih diutamakan pemahaman terhadap hak-hak anak yang harus dilindungi karena secara kodrat anak memiliki substansi yang lemah dan rentan terhadap pertanggung jawaban atas dirinya sendiri, sedangkan menurut Undang-undang RI Nomor 39 Tahun 1999 tentang Hak Asasi Manusia pasal 52 menyebutkan bahwa "Hak anak adalah hak asasi manusia dan untuk kepentingannya hak anak itu diakui dan dilindungi oleh hukum bahkan sejak dalam kandungannya". Batas usia anak menurut ketentuan pidana dirumuskan dengan jelas dalam pasal 1 butir 1 UU RI Nomor 3 Tahun 1997 Tentang Pengadilan Anak yang berbunyi "Anak adalah orang yang berada dalam perkara anak nakal telah mencapai umur 8 (delapan) tahun tetapi belum mencapai umur 18 (delapan belas) tahun dan belum pernah kawin".

Masalah perlindungan hukum dan hak-haknya bagi anak-anak merupakan salah satu sisi pendekatan untuk melindungi anak-anak Indonesia. Agar perlindungan terhadap hak-hak anak dapat dilakukan secara teratur, tertib dan tanggung jawab maka diperlukan peraturan hukum yang selaras dengan perkembangan masyarakat Indonesia yang dijiwai sepenuhnya oleh Pancasila dan Undang-Undang Dasar Negara Republik Indonesia Tahun 1945.

Anak hendaknya diberi perlindungan khusus sehingga mampu mengembang tanggung jawab dalam masyarakat. Anak seharusnya diperlakukan dengan baik dalam lingkungan keluarga yang bahagia, penuh kasih sayang dan perhatian dari keluarga. Beberapa tahun terakhir ini kejahatan terhadap orang dewasa maupun terhadap anak semakin meningkat baik kualitas maupun kuantitas. Seiring dengan kemajuan teknologi dan peradaban manusia. Kejahatan yang terjadi tidak hanya menyangkut kejahatan terhadap nyawa, harta benda akan tetapi kejahatan terhadap kesusilaan juga semakin meningkat. Hal tersebut berhubungannya dengan kejahatan kesusilaan sering terjadi pada krisis sosial dan perkembangan dimana keadilan tersebut tidak akan lepas dari peranan kaidah sosial yang ada, bahkan anak-anak menjadi salah satu akibat dari konflik kejiwaan dengan munculnya perilaku masyarakat dalam bentuk perbuatan asusila yang menyimpang kaidah-kaidah yang ada yaitu kaidah sosial, kaidah hukum, dan 


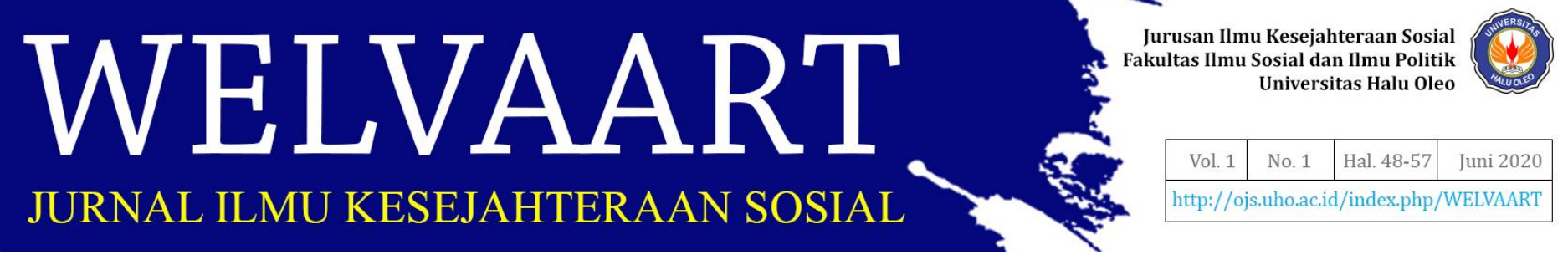

kaidah agama. Kejahatan kesusilaan yang dalam hal ini adalah tindak pidana asusila terhadap anak dibawah umur kejahatan yang sangat minim alat bukti.

Korban kejahatan kesusilaan tidak tahu bahwa ia baru saja mengalami kekerasan seksual atau tindakan asusila lain karena kepolosan mereka untuk memahami peristiwa tersebut atau telah mengalami rasa takut yang berlebihan. Menurut Supadmi (2000) menyatakan bahwa restorative justice menjadi pilihan yang harus diutamakan untuk melindungi anak. Penelitian tersebut menemukan bahwa di dalam sistem peradilan pidana anak, pendekatan yang cocok diterapkan adalah keadilan restoratif. Fokus dari pendekatan ini adalah (1) memperbaiki kerusakan sosial yang diakibatkan oleh pelaku melalui pertanggung jawaban pelaku terhadap korban atas tindakan kejahatan yang telah dilakukan, serta (2) mengembalikan kembali (reintegrasi) pelaku kejahatan kepada masyarakat. Dengan memakai pendekatan keadilan restoratif kemungkinan masyarakat untuk menerima kembali pelaku anak akan lebih besar dari pada terhadap pelaku dewasa (Dermawan, 2007). Restorative justice (dalam bahasa Indonesia diterjemahkan sebagai keadilan restoratif atau keadilan yang memulihkan) adalah diskursus baru dalam sistem hukum Indonesia yang menawarkan solusi yang komprehensif dalam menangani permasalahan $\mathrm{ABH}$. Restorative justice merupakan alternatif penyelesaian perkara dimana semua komponen yang terkait dengan perkara yang melibatkan anak untuk duduk bersama guna merumuskan secara kolektif cara mengatasi konsekuensi pelanggaran hukum yang dilakukan oleh anak dan implikasinya di masa mendatang (Firdaus 2008). Pendekatan ini menekankan akan adanya kebutuhan dan pentingnya melakukan reintegrasi anak yang telah berhadapan dengan hukum. Penyelesaian perkara dengan mekanisme Restorative justice lebih bersifat informal dan personal dan pada umumnya dilaksanakan dengan melakukan mediasi melalui komunitas secara kekeluargaan. Pada kasus-kasus dimana ABH dianggap perlu menjalani proses hukum secara formal, keputusan yang diambil dapat berupa penangguhan penahanan, anak dikembalikan kepada orang tua, pidana bersyarat, pidana percobaan, atau penempatan anak dalam lembaga (Lembaga Pembinan Khusus Anak) (Dermawan, 2007).

Konsep keadilan restoratif pada intinya terletak pada konsep komunitas yang peduli dan inklusif (Supeno, 2010). Dalam hal ini, jika dikaitkan dengan model pelayanan kesejahteraan sosial bagi anak, konsep keadilan restoratif akan banyak menekankan pada Community Based Service. Konsep keadilan restoratif pada intinya terletak pada konsep perlunya keterlibatan masyarakat dalam menangani permasalahan anak dan dalam hal ini pekerja sosial dapat ikut berperan melalui intervensi komunitas agar masyarakat dapat berpartisipasi dalam penanganan masalah ABH. Pekerja Sosial sebagai SDM utama dalam pelayanan bimbingan dan pendampingan anak saat ini dituntut untuk lebih proaktif dan inovatif sesuai dengan tuntutan perkembangan. Jika terjadi konflik, praktek restoratif akan menangani pihak pelaku, korban, dan pihak-pihak lain yang terkait dalam komunitas secara kolektif untuk memecahkan masalah yang terjadi. Tujuannya adalah untuk memperbaiki kerusakan, memulihkan kualitas hubungan, dan memfasilitasi reintegrasi para pihak yang terlibat dan terkait. Oleh karena itu peran pekerja sosial akan lebih dari hanya melakukan konseling dan memberi pembinaan keterampilan dan latihan kerja di lingkungan panti, tetapi menjadi lebih luas dengan melakukan kegiatan di lingkungan masyarakat melalui intervensi komunitas agar masyarakat dapat berpartisipasi dalam mereintegrasikan ABH. Dalam strategi pelayanan anak melalui Community Based Service pekerja sosial akan menjadi perancang dan pelaksana program pengembangan masyarakat (Suharto, 1997). Pekerja sosial juga akan memiliki peran besar dan dominan dalam pendekatan 


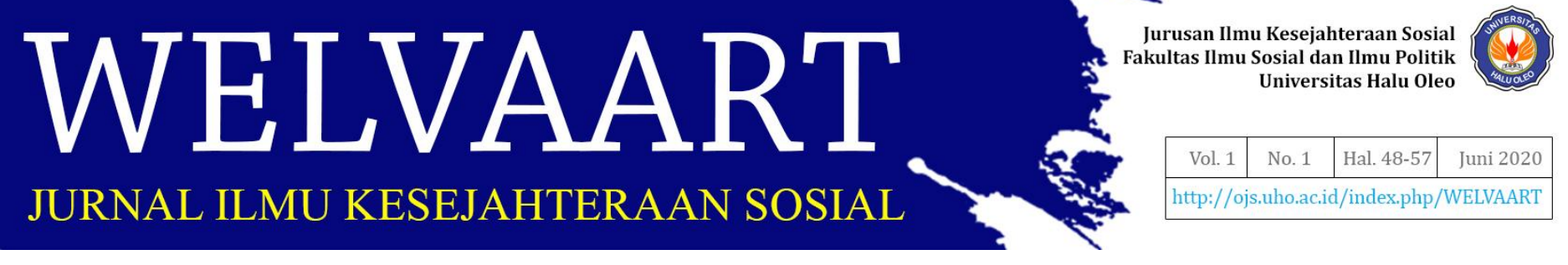

keadilan restoratif, di mana pekerja sosial akan tampil paling awal dan paling depan dalam proses mediasi pelaku dan korban kenakalan anak (Supeno, 2010).

Penanganan dan perlindungan anak yang mengedepankan pendekatan keadilan restoratif di Indonesia ditandai dengan diterbitkannya kesepakatan berupa MOU antara 6 lembaga negara; yaitu Menteri Sosial, Menteri Hukum dan HAM, Menteri Pendidikan Nasional, Menteri Kesehatan, Menteri Agama, dan Kepolisian Negara RI tentang Perlindungan dan Rehabilitasi Sosial Anak Yang Berhadapan dengan Hukum. MOU ini kemudian lebih ditegaskan dengan SKB Ketua Mahkamah Agung RI, Jaksa Agung, Kapolri, Menteri Hukum dan HAM, Menteri Sosial, dan Menteri Pemberdayaan Perempuan dan Perlindungan Anak tanggal 22 Desember 2009 tentang Penanganan Anak yang Berhadapan Dengan Hukum. Inti MOU adalah memberi perlindungan dan rehabilitasi sosial bagi $\mathrm{ABH}$ dengan mengutamakan pendekatan keadilan restoratif. maka dari itu tindakan asusila oleh anak yang terjadi merupakan suatu masalah yang memerlukan perhatian khusus pemerintah karena berkaitan dengan moralitas para generasi bangsa. Dalam hal ini pengadilan yang merupakan instansi atau lembaga yang menangani masalah hukum perlu memberikan perhatian terhadap kasus yang berkaitan dengan anak-anak terutama pada kesejahteraan asusila. Untuk pengadilan perlu memberikan sanksi yang paling tepat pada anak-anak yang melakukan tindak pidana terutama kejahatan seksual, pencabulan, penganiyayaan yang terdapat dalam pidana KUHP tentang tindak asusila.

Anak yang bermasalah pembinaannya ditempatkan di Lembaga Pembinaan Khusus Anak (LPKA). Lembaga Pembinaan Khusus Anak merupakan sarana perlindungan anak dan pembinaan bagi anak negara, anak sipil, dan anak pidana yang berdasarkan putusan pengadilan ditempatkan di Lapas Anak untuk dibina. Lembaga Pembinaan Khusus Anak adalah tempat pendidikan dan pembinaan bagi narapidana anak. Sasaran akhir dari kehadiran lembaga pemasyarakatan adalah pembinaan. Di dalam lembaga pemasyarakatan narapidana anak dilindungi dan dibina agar dapat menyongsong masa depan dengan lebih baik, melalui pembinaan narapidan anak akan memperoleh jati dirinya untuk menjadi manusia yang mandiri, bertanggung jawab dan berguna bagi dirinya sendiri, keluarga, masyarakat, bangsa dan negaranya.

Salah satu Lapas Anak di Indonesia yang terdapat di Sulwesi Tenggara adalah Lembaga Pembinaan Khusus Anak Kelas II Kendari. merupakan salah satu Unit Pelaksana Teknis Pemasyarakatan yang berada di bawah Kantor Wilayah Kementrian Hukum Dan Hak Asasi Manusia Sulawesi Tenggara. Lembaga Pembinaan Khusus Anak Kelas II Kendari berdiri sejak tahun 2015 dan diresmikan tahun 2017. Jumlah penghuni Lembaga Pembinaan Khusus Anak Kelas II Kendari pada awal Tahun 2017 berjumlah 26 orang yang terdiri dari: pembunuhan 1 orang, pencurian 7 orang, Terhadap ketertiban 1 orang, penganiayaan 3 orang, kesusilaan 1 orang dan tindakan Asusila 13 orang. dan yang sudah jatuh vonis 21 dan yang belum jatuh vonis 5 mereka berasal dari kalangan keluarga mampu kemudian Rata-rata memiliki asal usul daerah yang berbeda antara lain berasal dari buton, muna, Bau - bau, konawe, kendari, raha, dan kolaka. (sumber: Lembaga Pemasyara katan Kelas II Kendari). Rumusan Masalah 1. Bagaimanakah bentuk kasus tindak asusila yang dilakukan anak 2. Apakah faktor penyebab terjadinya kasus tindak asusila yang dilakukan anak 3. Bagaimanakah Proses penanganan anak bermasalah dengan hukum $(\mathrm{ABH})$ dalam kasus tindak asusila di Lembaga Pembinaan Khusus anak Kelas II kendari. Tujuan Penelitian 1. Untuk mendiskripsikan bentuk kasus tindak asusila yang dilakukan anak 2. Untuk mendiskripsikan faktor penyebab terjadinya kasus tindak asusila 


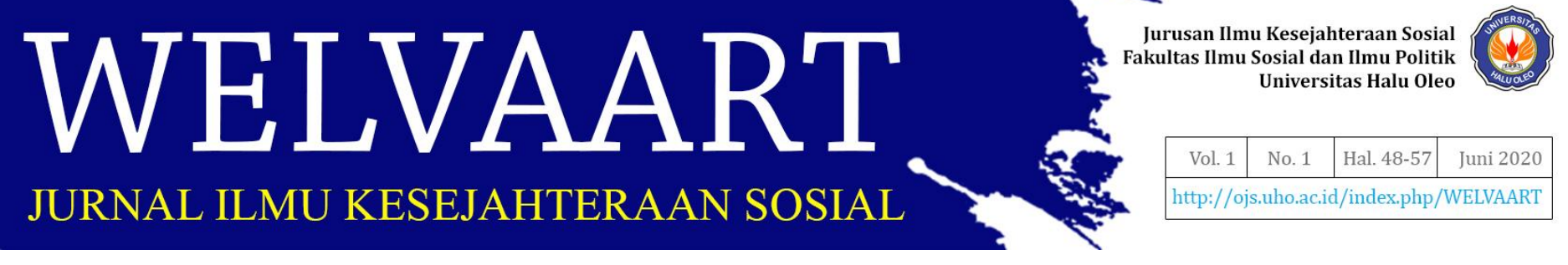

yang dilakukan anak 3. Untuk mendeskripsikan proses penanganan anak bermasalah dengan hukum $(\mathrm{ABH})$ dalam kasus tindak asusila di Lembaga Pembinaan Khusus anak Kelas II kendari.

\section{METODE PENELITIAN}

Lokasi dalam penelitian ini bertempat di Lembaga Pembinaan Khusus Anak kelas II Kendari. Penelitian ini bersifat deskriptif kualitatif yang mendeskripsikan mengenai, 1. Apa Saja Bentuk Tindak Asusila Yang Dilakukan Oleh Anak 2. Apa saja faktor penyebab tindak asusila yang dilakukan anak dan 3. bagaimanakah solusi bagi anak yang berhadapan dengan hukum kasus asusila Di Lembaga Pembinaan Khusus Anak Kelas II Kendari. Deskriptif kualitatif adalah mengkaji, menjelaskan, atau memaparkan dengan terperinci. Penentuan informan dilakukan peneliti menggunakan teknik purposive sampling, dimana menurut Sugiono (2009) purposive sampling yaitu pengambilan sampel sumber data dengan pertimbangan tertentu misalnya orang tersebut dianggap paling tahu tentang informasi yang peneliti harapkan atau mungkin dia sebagai penguasa sehingga akan memudahkan peneliti menjelajahi objek atau situasi tertentu. Dalam sebuah penelitian diperlukan orang-orang yang akan peneliti pilih sebagai pemberi informasi mengenai data yang diperlukan. Informan dalam penelitian ini adalah anak binaan yang mendapatkan penanganan sebanyak 5 (Lima ) orang, dan pegawai lapas yang memberikan pembinaan kepada anak binaan 4 (empat) orang, dan 1 orang dari pihak konselor atau pekerja sosial sebagai informan tambahan. jenis data dalam penelitian ini adalah data kualitatif dan kuantiatif. Sumber data dalam penelitian ini adalah :Data primer adalah data yang bersumber dari suatu penelitian lapangan, yaitu suatu data yang diperoleh langsung dari sumber lapangan yaitu baik responden maupun informan. Data primer yang digunakan dalam penulisan penelitian ini adalah dengan melakukan wawancara langsung mengenai proses penanganaan anak tindak asusila di LPKA Kelas II Kendari. Data sekunder yaitu data yang berupa catatan-catatan dari dokumen yang terdapat di LPKA Kelas II Kendari. Jenis Data primer dan data sekunder maka peneliti melakukan pengumpulan data dengan menggunakan tehnik studi lapangan (field research) yaitu mengumpulkan data-data secara langsung dilapangan, yang digunakan dengan menggunakan metode sebagai berikut:

Teknik Pengumpulan Data Pengamatan (observasi) yaitu peninjauan secara cermat terhadap wilayah penelitian guna memperoleh gambaran tentang proses pembinaan di LPKA Kelas II Kendari Wawancara (interview) yaitu melakukan tanya jawab secara langsung pada informan yang kemudian hal ini langsung kepada informan kunci maupun informan tambahan untuk mendapatkan data mengenai masalah yang diteliti. Wawancara terus dilakukan selama berlangsungnya penelitian sehingga mencapai data yang jenuh dalam hal ini sampai pada ambang batas pengetahuan dengan kata lain informan yang memberikan informasi tidak ditemukan lagi data baru.

Teknik Analisa Data Menurut Moleong (2004), proses analisis data dimulai dengan menelaah seluruh data yang telah tersedia dari berbagai sumber, yaitu dari wawancara, pengamatan yang sudah dilakukan dalam catatan lapangan, dokumen pribadi, dokumen resmi, gambar, foto, dan sebagainya.adapun analisis data yang di lakukan mengikuti pola sebagaimana yang disistematiskan oleh miles dan huberman

\section{PEMBAHASAN}

\section{A. Gambaran umum lokasi penelitian}




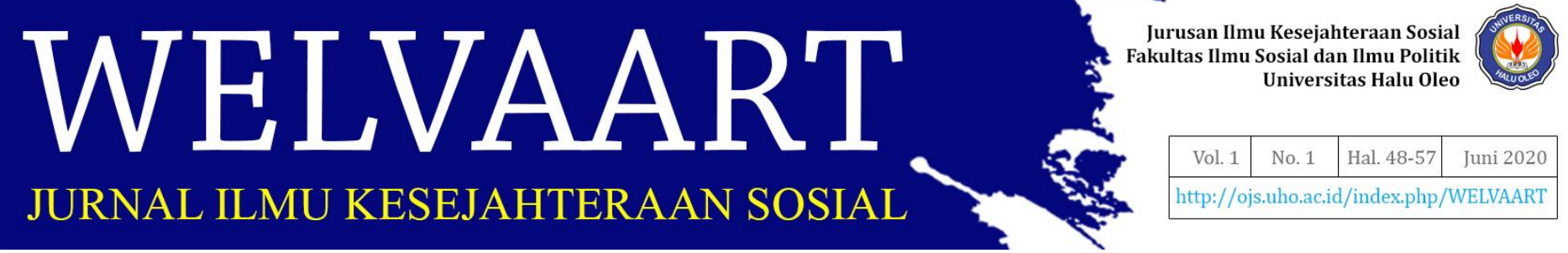

Lembaga Pembiaan Khusus Anak Kelas II Kendari beralamat di Jl. Piere Tendean

Kelurahan Baruga Kecamatan Baruga Kota Kendari. Letak lokasi berdirinya lembaga Pembinaan Khusus Anak Kelas II Kendari bersampingan dengan bangunan LAPAS dewasa. Kondisi saat ini LPKA masih bangunan darurat meminjam sebagian gedung dari LAPAS dewasa. Lembaga Pembinaan Khusus Anak Kelas II Kendari ini berdiri sejak tahun 2015 dan diresmikan oleh Kanwil Kementrian Hukum dan Hak Asasi Manusia Sulawesi Tenggara. secara keseluruhan yang di bina oleh LPKA berjumlah 26 orang yang terdiri dari macam macam kasus dan untuk kasus tindak Asusila itu sendiri berjumlah 14 (empat belas) orang yang memiliki daerah yang berbeda - beda.

\section{a. Visi dan Misi Lembaga Pembinaan Khusus Anak Kelas II Kendari}

Visi dan Misi Lembaga Pembinaan Khusus Anak Kelas II Kendari Menjadi lembaga pembinaan, pendidikan, dan lembaga pengembangan bagi anak didik pemasyarakatan yang cerdas, bermoral dan mandiri. Membina dan mendidik anak didik pemasyarakatan yang berkepribadian luhur, beriman dan bertakwa serta menguasai ilmu pengetahuan melalui pembinaan kemandirian dan kepribadian berdasarkan pancasila.

\section{b. Tujuan Pelayanan Lembaga pembinaan Khusus anak Kelas II Kendari} Berkepribadian luhur, Beriman dan bertakwa, Berilmu pengetahuan dan Mandiri Jumlah Pegawai Lembaga Pembinaan Kusus anak Dalam melaksanakan kegiatan Penanganan terhadap anak bermasalah dengan hukum Lembaga Pembinaan Khusus Anak memiliki jumlah pegawai negeri sipil (PNS) berjumlah 18 orang dan Jumlah anak bermasalah dengan hukum dalam kasus tindak asusila berjumlah 14 anak

\section{c. Gambaran umum kasus tindak asusila tahun 2017 sampai dengan} 2018

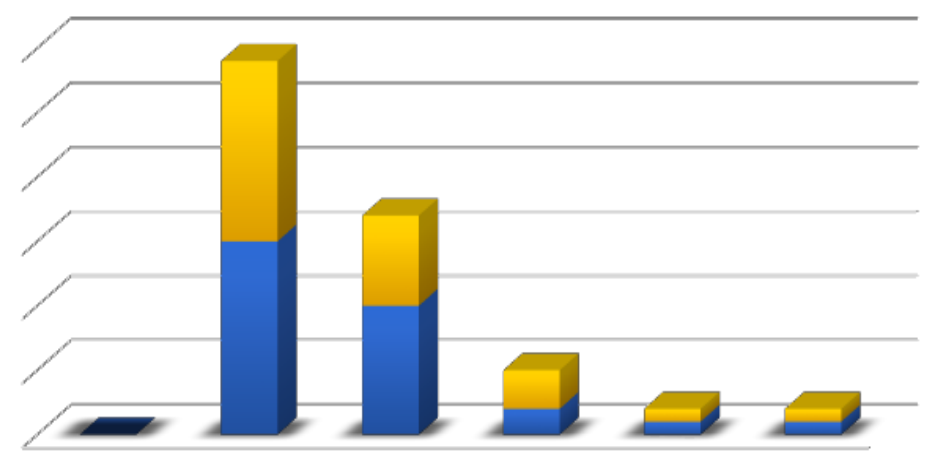

— Jumlah Kasus Anak Tahun 2017/2018 LPKA Kelas II Kendari

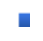

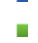

\begin{tabular}{|c|c|c|c|c|c|c|}
\hline & Nama Kasus & Asusila & pencurian & Penganiyayaan & pembunuhan & $\begin{array}{l}\text { Terhadap } \\
\text { Ketertiban }\end{array}$ \\
\hline Kasus di tahun 2017 & & 14 & 7 & 3 & 1 & 1 \\
\hline Kasus di tahun 2018 & 0 & 15 & 10 & 2 & 1 & 1 \\
\hline Kasus & & & & & & \\
\hline
\end{tabular}




\section{B. bentuk-bentuk tindak asusila yang di lakukan anak}

Bentuk asusila yang dilakukan oleh anak binaan LPKA Kelas II Kendari kepada korban yaitu meliputi menggoda atau menarik perhatian lawan jenis., upaya memaksa salah satu pihak, perbuatan memamerkan dan saling bersentuhan bagian aurat terlarang terhadap bukan mahrom.

\section{a. Ciuman dan Godaan yang di lakukan Pelaku terhadab Korban}

Ciuman dan Godaan yang di berikan pelaku terhadab korban adalah salah satu bentuk bagaimana pelaku mampu memberikan hasrat yang dia inginkannya terhadab korban

\section{b. Upaya memaksa salah satu pihak}

Upaya memaksa salah satu pihak adalah upaya yang dimana pihak yang satu memaksa untuk menuruti kemauannya apabila tidak di turuti kemauan tersebut maka pihak yang satu mengunakan segala cara untuk menuruti keinginanya

\section{Faktor-faktor penyebab tindak asusila pada anak}

Dari beberapa kasus anak berhadapan dengan hukum kasus tindak asusila ada beberapa faktor penyebab tindakan asusila pada anak yang mengakibatkan anak melakukan tindakan tersebut

\section{a. faktor internal}

Faktor interen adalah faktor yang terdapat dalam diri si pelaku artinya hal - hal yang mempunyai hubungan dengan kejahatan terhadap asusila di antaranya faktor bilogis dan moral

\section{b. faktor eksternal}

Faktor Eksternal ini adalah faktor yang berada di luar diri si pelaku artinya ada beberapa faktor seperti media dan kebiasaan berpacaran

D. Proses Penanganan Anak Yang Dilakukan LPKA Kelas II Kendari Penanganan anak merupakan suatu proses perbaikan diri dari tidak baik menjadi lebih baik dan mampu mengembangkan dan meningkatkan pengetahuan, keterampilan dan sikap yang bertujuan untuk lebih meningkatkan kemampuan seseorang atau kelompok dalam menyelesaikan suatu tugas atau pekerjaan secara teratur dan terencana sehingga penyelesaian tugas atau pekerjaan tersebut dapat dilakukan secara efisien dan efektif. Adapun proses penanganan terhadap anak binaan yaitu proses advokasi, penerapan pendidikan non formal, penerapan pendidikan agama, penerapan pendekatan informatif, penerapan pendekatan partisipatif dan penerapan pendekatan eksperensial

\section{a. Bentuk advokasi anak}

Di dalam advokasi pekerja sosial terutama kaitanya dengan perlindungan anak bagaimana advokasi untuk membantu agar klien anak dan keluarga mampu mendapatkan hak - hak anak dan pelayanan dengan baik

\section{b. Penerapan Pendidikan beragama}

Penerapan pendidikan agama dalam LPKA adalah salah satu bentuk penanganan bagaimana anak mampu Melalui pendidikan dan pengajaran, berdampak pada akhlak yang baik. sebagai generasi muda apabila seseorang yang pada awalnya belum begitu mengetahui tentang ilmu agama, kemudian ia mempunyai niat untuk memperdalam ilmu agamanya dengan cara 


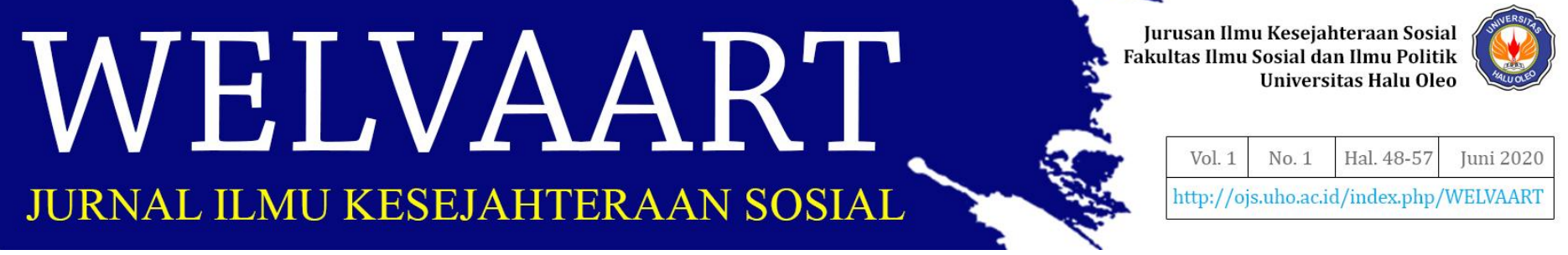

menuntut ilmu didalam keluarga mupun sekolahnya yang berbasis agama, maka dengan seiring berjalannya waktu ia akan mengerti tentang ilmu agama

\section{c. Penerapan pendidikan non formal (sekolah) dalam LPKA}

Usaha ini diperlukan agar pengetahuan serta kemampuan berfikir warga binaan pemasyarakatan semakin meningkat sehingga dapat menunjang kegiatan- kegiatan positif yang diperlukan selama masa pembinaan.

\section{d. Penerapan pendekatan Informatif (informative approaceh)}

Di dalam metode ini bagaimana anak binaan diberikan pendidikan dan keterampilan agar ilmu semasa SMA, SMP dan SD tidak putus begitu sajah dan pada saat massa kurungan berakhir mereka mampu mengimbangi pendidikan mereka yang sempat tertunda dengan kasus yang mereka lakukan

\section{e. Pendekatan Partisipatif (Partisivative Approaceh}

Pendekatan ini bertujuan untuk bagaimana anak di tuntun untuk memberikan pengetahuan terbaik mereka terhadap sesama anak binaan dalam hal ini lebih ke situasi belajar bersama. Didalam penanganan anak bermasalah dengan hukum masyarakat memandang mereka sebagai anak yang kehidupan mereka di liputi hal - hal yang tidak baik dan ujung dari kesimpulan mereka adalah buruk padahal ketika mereka melihat kemauan belajar dan potensi yang mereka miliki sangat begitu baik ketika orang tua dan keluarganya ikut serta menggali potensi pada anak mereka maka mereka akan menemukan keistimewaan dalam diri anak

\section{f. Pendekatan Eksperensial (Experiencial approach)}

Pendekatan ini bertujuan untuk bagaimana menuntun anak binaan langsung terlibat dalam proses penanganan hal ini yang di maksud sebagai belajar yang sejati karena pengalaman pribadi yang langsung terlihat dalam situasi tersebut

\section{KESIMPULAN}

\section{A. Kesimpulan}

Berdasarkan data-data yang ditemukan selama proses penelitian, maka diperoleh beberapa kesimpulan tentang tindakan asusila yang dilakukan anak binaan LPKA faktor - fakto penyebab tindak asusila, bentuk tindak tindak asusila dan proses penanganan anak kasus tindak asusila selama berada di LPKA. Faktor-faktor penyebab tindak asusila : faktor interen yaitu faktor yang terdapat dalam diri si pelaku seperti ,nafsu biologis dan moral yang dimana faktor biologis yang ingin di penuhinya, dan moral yang tidak baik yang mengakibatkan perilaku buruk yang munjul dalam diri si pelaku, faktor eksteren yaitu faktor yang ada di luar diri si pelaku seperti media massa, dan kebiasaan berpacaran yang mengakibatkan pelaku mendatangkan sendiri sifat - sifat negatif dalam dirinya, Bentuk tindak asusila yang dilakukan oleh anak binaan yaitu: upaya memaksa salah satu pihak dan Ciuman dan Godaan yang di lakukan Pelaku terhadab Korban. Proses penanganan yang di lakukan Lembaga pembinaan khusus anak kelas II Kendari yaitu : Penerapan advokasi anak, penerapan pendidikan agama, penerapan pendekatan informatif, penerapan pendekatan partisipatif dan penerapan pendekatan eksperensial.

\section{B. Saran}

Adapun hasil temuan dan hasil pengamatan di lapangan mengenai kasus tindak asusila bahwasanya mengenai kasus tindak asusila yang dilakukan oleh anak binaan bahwa kebanyakan dari anak melakukan tindakan asusila karna kurangnya iman yang dimiliki anak sehingga anak 


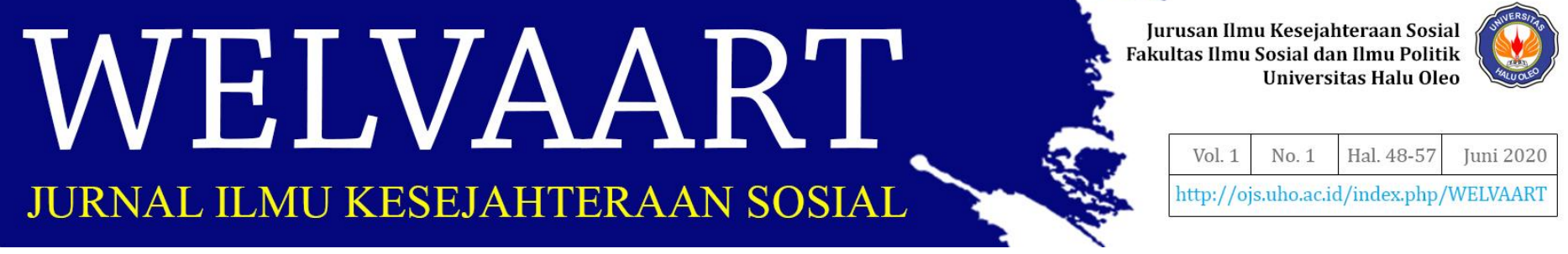

tidak dapat mengendalikan diri saat keadaan nafsu yang ada pada dirinya tidak mampu mengendalikanya. Didalam penanganan anak yang tersangkut tindakan asusila adalah salah satu bentuk perilaku keseharian yang sangat buruk apa yang saya amati dalam LPKA cenderung menganggab bahwasanya perbuatan yang mereka lakukan seakan akan seperti biasa sajah disinilah seharusnya dalam penanganan asusila yang dilakukan LPKA harus lebih ditekankan dalm proses perubahan anak binaan karena penekanan dalam proses penanganan mampu memberikan kesadaran mendalam bagi anak terhadap apa yang dia perbuat dan ini menjadi perhatian bagi orang tua dimana seharusnya mereka menanamkan agama yang sesungguhnya pada anak mereka karena agama sesuatu yang mengatur hidup manusia dari dia bagun tidur sampai tidur kembali bagaimana orang tua mengajarkan pentingnya akidah dalam kehidupan sehari - hari karena lingkungan untuk zaman sekarang begitu rusak dari pergaulan sampai media massa yang begitu meningkat siapapun mampu mengunakanya maka dari itu membutuhkan pegangan hidup yaitu iman. kemudian penanganan anak yang tersangkut tindak asusila yang di lakukan oleh LPKA adalah suatu penanganan yang memberikan nilai tersendiri dalam diri pelaku untuk sebisa mungkin menghilangkan kebiasaan buruk yang sehari - hari mereka lakukan dalam lingkungan mereka, kemudian bagaimana penanganan yang di lakukan LPKA untuk anak binaan mampu memberikan subangsi pengetahuan mereka untuk anak binaan lainya dan bagaimana sebisa mungkin memandirikan diri mereka sendiri kearah lebih maju dan bagaimana menghilangkan keburukan yang selama ini mereka lakukan dalam lingkungan mereka.

\section{DAFTAR PUSTAKA}

\section{Sumber Buku :}

Arikunto, Suharsimi. 2010. Perosedur Penelitian Suatu Pendekatan Praktik, Rineca Cipta : Jakarta

Dermawan, Mohammad Kemal, (2007). Analisis Situasi Anak Yang Berhadapan dengan Hukum di Indonesia, Unicef dan Pusat Kajian Kriminologi FISIP UI : Jakarta.

Huraerah, Abu. 2006. Kekerasan terhadap Anak, Penerbit Nuansa : Bandung

Harlen V Sinaga. "Dasar-Dasar Profesi Advokat", Erlangga : Jakarta 2011.

Firdaus, Moh. Syafari, et al. (2008). Membongkar Ingatan Berbagi Pengalaman Kumpulan Catatan Pengalaman, Pustaka LAHA : Bandung.

Kusumo, Wiryono (2015) pengertian hukum dan hukum ekonomi, Edisi Revisi, Grasindo, : Jakarta

Kan, Van (11 februari 2010) hukum adalah peraturan hidup jurnal hukum online, Jakarta.

Muladi \& Nawawi, Barda. 1992. Bunga Rampai Hukum Pidana, Alumni : bandung. Mappiare, Andi, (2005), Psikologi Remaja, Usaha Nasional : Surabaya.

Moleong, Lexy. 2004. Metodologi Penelitian Kualitatif, PT Remaja Rosdakarya : bandung.

Mansari, SH., MH, Restorative Justice. Banda Aceh: 2016

Purnomo, Bambang. 2005. Pelaksanan Pidana Penjara Dengan Sistim Pemasyarakatan, liberty: Yogyakarta.

Prakoso, abintoro. (2016) pembaruan sistem peradilan pidana anak, CV Aswaja Prssindo : Yogyakarta.

Purnianti, Supadmi, Mamik S. dan Martin, N. M. (2002). Analisis Situasi Sistem Peradilan Pidana Anak di Indonesia. UNICEF Perwakilan : Jakarta Indonesia. 


\section{WELVAART \\ JURNAL ILMU KESEJAHTERAAN SOSIAL}

Suharto Edi. "Membangun Masyarakat Memberdayakan Rakyat: Kajian Strategis Pembangunan Kesejahteraan Sosial dan Pekerjaan Sosial”,PT. Refika Aditama: Bandung, 2009.

Sudarto, 1981 Kapita Selekta Hukum Pidana, Alumni : Bandung

Sutedjo, Wagiati. 2006 Hukum Pidana Anak, Refika Aditama : Bandung

Sanusi, Has. 2004. Sistem Pemasyarakatan Di Indonesia, Jakarta: Bumi Aksara

Sugiyono. 2009. Metode Penelitian Kuantitatif Kualitatif Dan R/D, Alfabeta : Bandung.

Shalahuddin Odi. 2011 konvensi hak anak, baltira : Jakarta

Sudarsono. 2004. Kenakalan Remaja: Prevensi, Rehabilitasi, dan Resosialisasi. Jakarta: Rineka Cipta.

Singgih D. Gunarsa. 1992 . Psikologi Remaja, Gunung Mulia, Jakarta.

Soesilo, R., 1991, Kitab Undang-Undang Hukum Pidana (KUHP), Politeia : Bogor

Setiawan, Davit, 2014. Perlindungan Hukum Terhadap Anak Korban Kejahatan, KPAI : Jakarta.

Supeno, Hadi. (2010). Kriminalisasi Anak Tawaran Gagasan Radikal Peradilan Anak Tanpa Pemidanaan. PT. Gramedia Pustaka Utama : Jakarta

Soeharto, Edi. (1997). Pembangunan Kebijakan Sosial dan Pekerjaan Sosial, Spektrum Pemikiran. LSP-STKS : Bandung.

Utrecht definisi hukum ialah himpunan peratura 2005, Hukum dalam Ekonomi, Edisi Revisi, Grasindo : Jakarta.

Utamadi, Guntoro dan Paramita Utamadi (2001). Pelecehan Seksual, garafindo : Jakarta.

Unswagati, 2005 Kesejahteraan kesusilaan prespektif agama dan hukum, Universitas Swadaya Gunung Jati : Cirebon

Wickman, Randal Easton., Janet West. 2002. Therapeutic Work with Sexually Abused Children, Sage Publications : Landon

\section{Sumber Lain :}

Undang-Undang Nomor 35 Tahun 2014 Tentang Perlindungan Anak

Kitab Undang-Undang Hukum Pidana

Undang-Undang Nomor 3 Tahun 1997 tentang Peradilan anak

Undang-Undang Nomor 11 Tahun 2012 tentang Sistem Peradilan Pidana Anak Pasal

81 ayat (1) dan (2).

Buku ke Dua Bab XIV Undang - Undang kejahatan terhadap kesusilaan

Undang - Undang No. 44 Tahun 2008 tentang Norma Kesusilaan sebagai Batasan

Pornografi

Undang-Undang No. 11 Tahun 2009 tentang Kesejahteraan SosiaL

Keputusan Presiden Nomor 36 Tahun 1990 tentang Pengesahan Convention on the

Rights of the Child (Konvensi Hak-Hak Anak)

Kesepakatan Bersama Antara Menteri Sosial RI, Menteri Hukum dan HAM RI, Menteri Pendidikan Nasional RI, Menteri Kesehatan RI, Menteri Agama RI, dan Kepolisian Negara RI; Nomor : 12/PRS-2/KPTS/2009; Nomor : M.HH.04.MH.03.02.Th.2009; Nomor 11/XII/KB/2009; Nomor :

1220/Menkes/SKBXII/2009; Nomor : 06/ XII/2009; Nomor : B/43/XII/2009, tentang Perlindungan dan Rehabilitasi Sosial Anak Yang Berhadapan dengan Hukum 